Certified Emission Reduction (CER). Being a unit issued by the CDM executive board pursuant to Article 12 of the Kyoto Protocol, one CER is equal to one metric tonne of $\mathrm{CO}_{2}$ equivalent. In order to address impermanence, there are two types of CERs that parties could choose:

- a temporary CER (tCER), which expires at the end of the commitment period following the one during which it was issued; and

- a long-term CER (ICER), which expires at the end of the crediting period of the A/R CDM project activity.

Crediting period. The crediting period for an A/R CDM project activity is the period for which net anthropogenic GHG removals by sinks are verified and certified by a the designated operational entity (DOE) for the purpose of issuance of CER. Project participants may choose between two options for the length of a crediting period:

- fixed crediting period: a crediting period of a maximum of 30 years without possibility of renewal or extension once the proposed A/R CDM project activity has been registered; and

- renewable crediting period: a crediting period of a maximum of 20 years which may be renewed up to two times (maximum 60 years) provided that, for each renewal, the DOE determines that the original project baseline is still valid or has been updated taking account of new data.

A crediting period shall not extend beyond the operational lifetime of the A/R CDM project activity.

Leakage. Leakage is the increase in GHG emissions by sources outside the boundary of an A/R CDM project activity that is measurable and attributable to the A/R CDM project activity.

Reforestation. Reforestation is the direct, human-induced conversion of unforested land to forested land through planting, seeding, and/or the human-induced promotion of natural seed sources on land that had been forested but was converted to unforested land. For the first commitment period, reforestation activities are limited to lands that did not contain forest on 31 December 1989.

\section{Institutions involved}

The project cycle will directly and indirectly involve the following processes and institutions:

Conference of Parties (CoP). The CoP is the highest decision-making body in the United Nations Framework Convention on Climate Change (UNFCCC). The meeting of Parties of the Kyoto Protocol (MoP) may be held in conjunction with the CoP.

Executive Board (EB). Formed by the COP, the EB reports to the COP and MoP. Its main role is to supervise the implementation of CDM. The EB can recommend the revision and amendment of modalities and procedures of CDM implementation, approve methodological issues, and recommend the accreditation of a designated operational entity to CoP and MoP.

Designated Operational Entity (DOE). An entity designated by the CoP and MoP, the DOE is based on recommendation by the EB as qualified to validate proposed CDM project activities as well as verify and certify net anthropogenic GHG removals by sinks. A DOE shall not perform validation or verification and certification on the same A/R CDM project activity. Upon request, the EB may however allow a single DOE to perform all these functions within a single A/R CDM project activity.

Designated National Authority (DNA). An authority established by the national government, the DNA is required by the CoP to ensure that projects are consistent with national policies. It may comprise various types of agencies or institutions depending on the need of Parties.

\section{The Project Cycle}

The followings are steps to take in the project cycle

Approval. As soon as the project design document (PDD) is developed, it should go through the DNA approval process. The process, which is facilitated by the Secretariat, will not take more than six weeks by involving the Technical Committee, Expert Panel, and Stakeholder Forum. In case a PDD is not approved the project developer has to revise the document and resubmit it to the DNA (see Figure 1). 


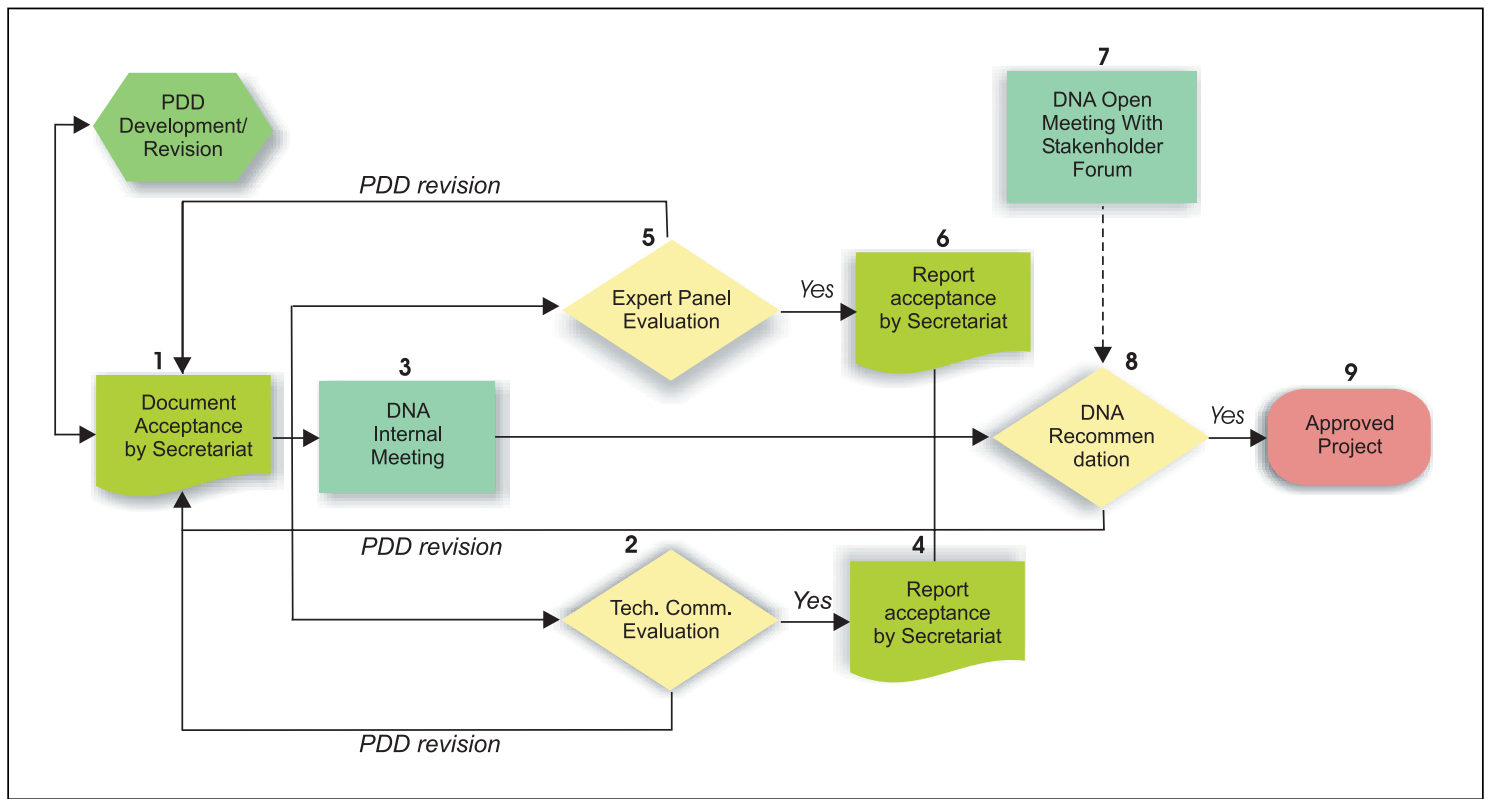

Figure 1. Approval process of a project design document (PDD) by the Designated National Authority (DNA) in Indonesia. Numbers indicate the order of steps to be taken within a six-week period.

Project developers or participants, which consist of investor and host, may come forward themselves to the DNA or have their case facilitated by an intermediary on their behalf. The following steps may be followed (as shown in Figure 2).

Validation and registration. Validation is the process of independent evaluation of a proposed A/R CDM project activity under the CDM by the DOE against the requirements of afforestation and reforestation project activities under the CDM as set out in decision 19/CP.9, its annex, and relevant decisions of the CoP and MoP, on the basis of the PDD. Registration is the formal acceptance by the EB of a validated project as an A/R CDM project activity under the CDM. Registration is the prerequisite for verification, certification, and issuance of tCERs or ICERs relating to that A/R CDM project activity. Validation and registration should take not more than four and eight weeks, respectively.

Monitoring. Monitoring refers to the collection and archiving of all relevant data necessary for estimating or measuring the net anthropogenic GHG removals by sinks during the crediting period. The activities are carried out by the project participants.

Verification and certification. Verification is the periodic independent review and ex post facto determination by the DOE of the net anthropogenic GHG removals by sinks achieved by an A/R CDM project activity under the CDM since the project inception. Certification is the written assurance by a DOE that an A/R CDM project activity under the CDM achieved the net anthropogenic GHG removals by sinks since the start of the project as verified. The process will take 15 days.

CER issuance. Issuance of ICERs or tCERs refers to the instruction by the EB to the CDM registry administrator to issue a specified quantity of ICERs or tCERs for an A/R CDM project activity into the pending account of the EB in the CDM registry.

\section{Financing an A/R CDM project}

A CDM project could produce both conventional project output (e.g., good quality and functioning forest stands) and carbon benefits (CERs). The value of CERs and their impact on project viability are influenced by the following factors:

Quantity of CERs. The amount of $\mathrm{CO}_{2}$ removed by the project during the crediting period selected depends on project size and quality. 
Price of CERs. The price is determined in the carbon markets and highly speculative. Three market systems are available: project based market (baseline and credit), allowance market (cap and trade), and voluntary market.

Transaction costs. The transaction costs consist of upfront costs (project identification, negotiation, validation, and approval) and implementation costs (monitoring, verification, and certification). Large-scale projects have relatively low transaction costs while small-scale projects have relatively high transaction costs. Simplification of a small-scale project can, however, reduce transaction costs by up to 67 percent.

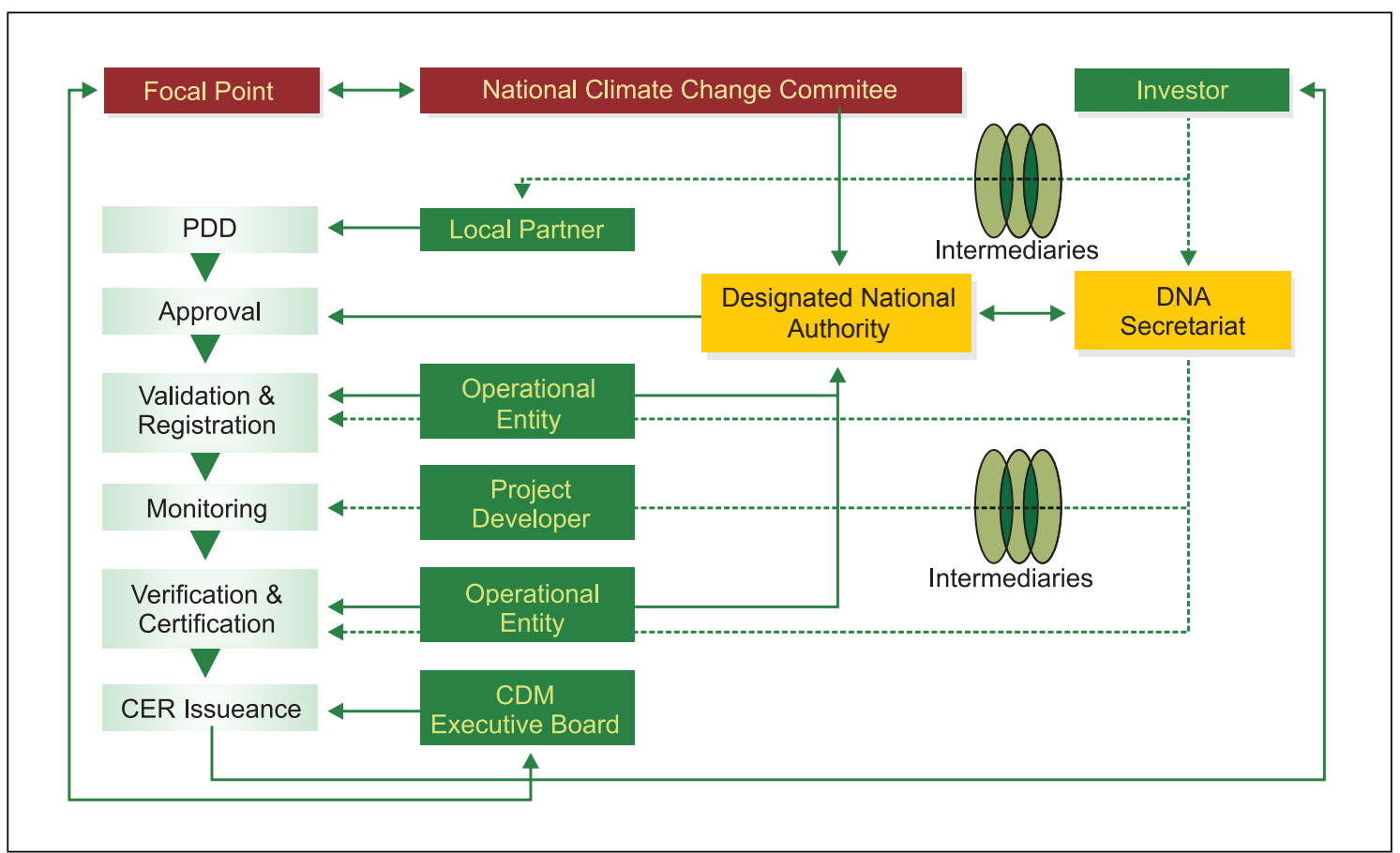

Figure 2. The project cycle involves a number of institutions.

This document is published in connection with the technical assistance provided by the Asian Development Bank (ADB) to the Government of Indonesia (Gol) on Carbon Sequestration Project through Clean Development Mechanism (Code: TA 4137-INO).
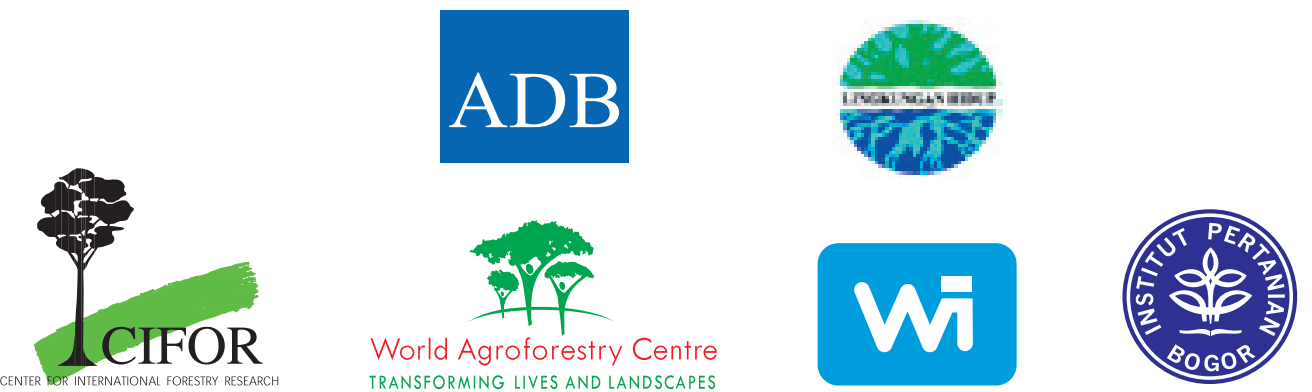

\section{CIFOR}

Center for International Forestry Research

Jalan CIFOR, Situ Gede, Bogor Barat 16680, Indonesia

Tel: +62 251622622 Fax: +62 251622100 E-mail: cifor@cgiar.org www.cifor.org 